\title{
ОРГАНИЗАЦИОННО-ПРАВОВОЙ МЕХАНИЗМ НАДЕЛЕНИЯ ПОЛНОМОЧИЯМИ НАРОДНЫХ СУДЕЙ В РСФСР ВО ВТОРОЙ ПОЛОВИНЕ 40-Х - НАЧАЛЕ 50-Х ГГ. ХХ в.
}

\begin{abstract}
Аннотация: В статье рассматривается история принятия положений «О выборах народных судов РСФСР» 1948 и 1951 г2. Анализируются нормы указанных актов, характеризуются основные стадии избирательного процесса по выборам народных судей, освещаются требования, предъявляемые к кандидатам. Отмечается, что иензы, закрепленные в положениях, были расширены за счет издания приказов министра юстиции СССР. Рассматриваются меры, предпринимаемые органами государственной власти и партийными организащиями для надлежамего обеспечения прочедуры проведения выборов. Делается вывод о том, что принятие актов о выборах народных судей, сыгравщее значительную роль в формировании статуса судей, означало важный шаг по пути к становлению действенной судейской независимости от органов исполнительной власти. Низкоквалифицированный состав судейского корпуса стал причиной повышения требований к кандидатам, что повлекло за собой внесение изменений не только в республиканское, но и в союзное законодательство. Abstract: The article examines the history of adopting the provisions of the "On Elections of People's Courts of the RSFSR" in the years 1948 and 1951. The norms of the specified acts are analyzed, the main stages of the electoral process for the election of people's judges are characterized, and the requirements for candidates are highlighted. It is noted that the qualification requirements set forth in the provisions were extended by the Minister of Justice of the USSR by issuing orders. The measures, taken by public authorities and party organizations in order to ensure the proper procedures for the election, are being considered. There is a conclusion that the adoption of acts on electing the people's judges, playing a significant role in the formation of the status of judges, constituted an important step on the way to achieving effective judicial independence from the executive authorities. The low-skilled part of the judiciary became the reason for increasing the requirements for candidates, which resulted in making changes not only in the Republican legislation, but also in the Union legislation.

Ключевые слова: РСФСР, Конституция, народньй судья, Советь, исполнительный комитет, выборы, министерство юстиции, закон, избирательный процесс, ценз.

Keywords: Russian Federation, Constitution, people's judge, councils, executive committee, elections, the Ministry of Justice, law, electoral process and qualification requirement.
\end{abstract}

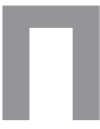

ринятие Конституции СССР 1936 г. стало началом нового этапа в развитии законодательства о формировании судейского корпуса в РСФСР, и прежде всего - в части наделения полномочиями судей. Начиная с прихода к власти большевиков в октябре 1917 г. основным способом наделения народных судей полномочиями являлись выборы Советами, а после судебной реформы 1922 г. - исполкомами ${ }^{1}$,

${ }^{1}$ См.: Декрет СНК РСФСР от 24.11.1917 г. «О суде» // СУ РСФСР. 1917. № 4. Ст. 50; Декрет ВЦИК от 07.03.1918 г. № 2 «О суде» // СУ РСФСР. 1918. № 26. Ст. 347; Декрет ВЦИК от 30.11. 1918 г. «Положение о Народном Суде Российской Социалистической Федеративной Советской Республики» // СУ РСФСР. 1918. № 28. Ст. 366; Декрет ВЦИК от 21.10.1920 г. «Положение о Народном что делало судей зависимыми от органов исполнительной власти.

Конституция СССР 1936 г. ${ }^{2}$, подтвердив принцип выборности судей, установила новый порядок наделе-

Суде Российской Социалистической Федеративной Советской Республики» // СУ РСФСР. 1920. № 83. Ст. 407; Постановление ВЦИК от 11.11.1922 «О введении в действие Положения о судоустройстве Р.С.Ф.С.Р.» // СУ РСФСР. 1922. № 69. Ст. 902; Постановление ВЦИК от 19.11.1926 г. «Об утверждении Положения о судоустройстве Р.С.Ф.С.Р.» // СУ РСФСР. 1926. № 85. Ст. 624.

${ }^{2}$ Конституция (Основной Закон) Союза Советских Социалистических Республик (утв. Постановлением Чрезвычайного VIII Съезда Советов СССР от 05.12.1936) // Известия ЦИК СССР и ВЦИК. № 283. 06.12.1936. 
ния их полномочиями. Так, выборы народных судей осуществлялись гражданами района на основе всеобщего, прямого и равного избирательного права при тайном голосовании (ст. 109). Причем, в избрании судей могли, а на практике и должны были принимать участие граждане, не имеющие постоянного места жительства на территории избирательного округа и появившиеся там незадолго до дня голосования.

«Во всех странах существуют различные формы ограничения избирательного права, - отмечал Н.В. Крыленко, выступая на собрании партийных, хозяйственных работников, пропагандистов и агитаторов в 1937 г.--Говорят для того, чтобы избирать, нужно, ну, прожить на том месте, где будет избирать хотя бы 2 , хотя бы 4, хотя бы 6 месяцев, хотя бы - 2 года, а некоторые говорят - 5 лет.

Наш Избирательный закон говорит: можешь жить один день в этом месте, к тебе придут и скажут - вы, гражданин, живете здесь? - здесь. Мы вас занесем в избирательные списки. Но я завтра уезду. И уезжайте, пожалуйста, мы вас все-таки запишем...») ${ }^{3}$ (орфография первоисточника сохранена. -Д.С.)

Принцип прямых выборов народных судей населением был закреплен и в законе СССР от 16.08.1938 г. «О судоустройстве СССР, союзных и автономных республик» ${ }^{4}$; процедуру выборов народных судей регулировали нормы ст. ст. 22-25 указанного закона. В то же время, данная процедура не была детализирована в связи с тем, что планировалось издание соответствующих республиканских актов, регламентирующих порядок наделения народных судей полномочиями.

Первый проект закона о выборах народных судей РСФСР был представлен наркомом юстиции СССР Н.В. Крыленко 26 октября 1937 г. - еще до принятия союзного закона о судоустройстве. Как отмечал сам нарком, избирательная техника преимущественно была заимствована из Положения о выборах в Верховный Совет ${ }^{5}$. Однако проект встретил отрицательную реакцию со стороны А.Я. Вышинского. «Разработанный Наркомюстом Союза ССР проект “Положения о выборах народных судей и народных заседателей”, - писал Прокурор СССР, -неразрывно связан с проектом “Положения о судоустройстве Союза ССР”. Это “Положение” должно, по моему мнению, представлять

\footnotetext{
${ }^{3}$ Государственный архив общественно-политической истории Курской области. Ф. 1. Оп. 1. Д. 917. Л. 32.

${ }^{4}$ Закон СССР от 16.08 .1938 г. «О судоустройстве СССР, союзных и автономных республик» // Ведомости ВС СССР. 1938. № 11.

${ }_{5}^{5}$ Государственный архив Российской Федерации (далее - ГА РФ). Ф. Р-8131. Оп. 14. Д 40. Л. 2.
}

собой одну из глав “Положения о судоустройстве”» 6 . Подверглись критике А.Я.Вышинского и отдельные нормы представленного законопроекта.

После принятия акта о судоустройстве 1938 г. вопрос о законодательном закреплении процедуры формирования судейского корпуса в РСФСР вновь встал на повестку дня. Разработка очередного проекта о выборах народных судей, тесно связанная с именем нового наркома юстиции СССР Н.М. Рычкова, затянулась почти на два с половиной года. 9 июня 1941 г. окончательно переработанный проект был представлен на рассмотрение Совнаркома СССР и одобрен, однако так и не вступил в силу из-за начавшихся военных действий.

После окончания Великой Отечественной войны вопрос о принятии закона о выборах народных судей приобрел особую актуальность. В Правительство СССР направлялось множество проектов, регулирующих процедуру выборов, однако рассмотрение их неизменно откладывалось. Наконец, 20 марта 1947 г. проект Положения о выборах народных судей и народных заседателей в РСФСР поступил в Совет Министров СССР, но дальнейшего движения не получил. Повторно он был внесен в Секретариат ЦК в июле 1948 г., рассматривался очень быстро и был утвержден Верховным Советом РСФСР 25 сентября 1948 г.

В преддверии принятия положения о выборах народных судов, 13 сентября 1948 г. Политбюро приняло решение о внесении изменений в ст. 11 Закона «О судоустройстве СССР, союзных и автономных республик» в части установления квалификационных требований для кандидатов на должность судей (ранее Конституция 1936 г. и принятый в развитие её положений указанный закон отменяли все цензы для кандидатов на должность судей). Законодатель, указав, что в народные судьи могут быть избраны граждане СССР, пользующиеся избирательным правом, установил возрастной ценз в 23 года, ввел моральный ценз: не могли избираться лица, имеющие судимость ${ }^{8}$. В тот же день 1948 г. Политбюро утвердило проект Указа Президиума Верховного Совета СССР «Об изменении ст.11 Закона о судоустройстве СССР, союзных и автономных республик»; уже 16 сентября Указ был принят 9 .

\footnotetext{
${ }^{6}$ Там же. Л. 6.

${ }^{7}$ Кодинщев А.Я. Выборы народных судей СССР в 1948 - 1954 гг.: [Электронный ресурс]. Доступ из справочно-правовой системы «КонсультантПлюс»

8 Российский государственный архив социально-политической истории (далее - РГАСПИ). Ф. 17. Оп. 3. Д. 1072. Л. 41.

${ }_{9}^{9}$ Указ Президиума Верховного Совета СССР «Об изменении ст. 11 Закона о судоустройстве СССР, союзных и автономных республик» // Ведомости Верховного Совета СССР. 1948. № 38.
} 
DOI: $10.7256 / 1811-9018.2014 .1 .10264$

При цитировании этой статьи сноска на dоі обязательна

\section{Право и политика 1 (169) • 2014}

В основу Положения «О выборах народных судов РСФСР $\rangle^{10} 1948$ г. был положен довоенный проект Н.М. Рычкова о выборах народных судей.

Выборы народных судов организовывались Президиумами Верховных Советов автономных республик и исполнительными комитетами краевых, областных Советов депутатов трудящихся через исполнительные комитеты районных и городских советов депутатов трудящихся (ст.22).

На исполкомы соответствующих уровней возлагались следующие обязанности:

a) регистрация кандидатов в народные судьи;

б) снабжение избирательных пунктов избирательными бюллетенями для выборов народных судей и народных заседателей по установленной форме;

в) назначение уполномоченных для приема избирательных бюллетеней и подсчета голосов по избирательным пунктам;

г) установление результатов выборов народного судьи по каждому избирательному округу;

д) выдача избранным в народные судьи удостоверений об избрании;

е) рассмотрение жалоб на неправильные действия уполномоченных по избирательным пунктам (ст.23).

Народные судьи избирались на три года на основе всеобщего, прямого и равного избирательного права при тайном голосовании.

Кандидат в народные судьи должен был соответствовать следующим требованиям:

1) иметь гражданство РСФСР;

2) пользоваться избирательными правами;

3) достичь ко дню выборов 23 лет;

4) отсутствие судимости (ч. 1-2 ст.1)

Иных цензов Положение «О выборах народных судов РСФСР» не устанавливало. Однако в приказе министра юстиции СССР от 25 сентября 1948 г. указывалось: «При подборе кандидатов учитывать, что народные судьи в республиканских, краевых и областных городах должны иметь, как правило, высшее или среднее юридическое образование или большой практический опыт работы в органах юстиции, суда и прокуратуры. Желательно, чтобы остальные народные судьи имели как минимум юридическое образование в объеме юридической школы или переподготовку в объеме... юридических курсов» ${ }^{11}$.

\footnotetext{
${ }^{10}$ Положение «О выборах народных судов РСФСР» (утв. Указом Президиума Верховного Совета РСФСР от 25 сентября 1948 г.) // ГА РФ. Ф. А-385. Оп. 26. Д. 74.

${ }^{11}$ ГА РФ. Ф. Р-9492. Оп. 4. Д. 401. Л. 68.
}

Право выдвижения кандидатов принадлежало общественным организациям и обществам трудящихся, в частности:

1) коммунистическим партийным организациям;

2) профессиональным союзам;

3) кооперативным организациям;

4) организациям молодёжи;

5) общим собраниям рабочих и служащих - по предприятиям и учреждениям;

6) общим собраниям военнослужащих - по воинским частям;

7) общим собраниям крестьян - по колхозам и селам;

8) общим собраниям рабочих и служащих совхозов - по совхозам (ст.26).

Регистрация кандидатов происходила не позднее, чем за 25 дней до выборов в исполнительном комитете районного или городского Совета депутатов трудящихся. Кандидат мог выдвигаться только в одном избирательном округе.

Исполком был обязан зарегистрировать всех кандидатов в народные судьи с соблюдением требований действующего законодательства. В случае отказа в регистрации действия соответствующего исполкома могли быть обжалованы в двухдневный срок в Президиум Верховного Совета автономной республики или в исполнительный комитет краевого, областного Совета депутатов трудящихся. Их решение являлось окончательным (ст.ст.26-30).

Основной избирательной единицей при выборах народных судей являлся избирательный округ, охватывающий все население, проживающее на территории деятельности данного народного суда (ст.4). В каждом избирательном округе избирался один судья (ст.14).

Списки избирателей составляли органы исполнительной власти: в городах - исполнительные комитеты районных Советов, в поселках - исполнительными комитетами поселковых Советов, в сельских местностях - исполнительными комитетами сельских Советов депутатов трудящихся.

В списки избирателей вносились лица, отвечающие следующим требованиям:

1) наличие гражданства;

2) проживание к моменту составления списков на территории данного Совета;

3) достигшие ко дню выборов 18 лет.

Не подлежали внесению в списки избирателей лица:

1) лишенные избирательных прав по суду - в течение всего установленного в приговоре срока лишения избирательных прав; 
2) признанные в установленном законом порядке умалишенными (ст.ст. 6-8)

День выборов по каждому избирательному округу устанавливался Президиумом Верховного Совета автономной республики, исполнительным комитетом краевого, областного Совета депутатов трудящихся. Обязательным условием законодатель называл проведение выборов в нерабочий день (ст.37).

Для приема избирательных бюллетеней и подсчета голосов на территории избирательного округа по выборам народного судьи образовывались избирательные пункты.

Формировали избирательные пункты не позднее, чем за 35 дней до выборов: в городах - исполнительные комитеты городских Советов депутатов трудящихся; в городах с районным делением - исполнительные комитетами районных советов депутатов трудящихся; в сельских местностях - исполнительные комитеты районных советов депутатов трудящихся (ст.ст.16-17).

Подача голосов избирателей производилась в день выборов от 6 часов утра до 12 часов ночи по местному времени (ст.38).

Каждый избиратель голосовал лично; избиратель, не имеющий возможности в силу неграмотности или какого-либо физического недостатка самостоятельно заполнить бюллетень, имел право пригласить в помещение, где заполняются избирательные бюллетени, любого другого избирателя для заполнения избирательных бюллетеней (ст.ст. 40,44)

Для подсчета голосов, поданных за каждого кандидата в народные судьи, исполкомы районных и городских Советов депутатов трудящихся образовывали счетные комиссии в составе 5-7 человек по каждому избирательному округу. Счетная комиссия в составе 5-11 человек формировалась при уполномоченном соответствующего исполкома для подсчета голосов, поданных за кандидата в народные судьи, в каждом избирательном пункте (ст.ст.24-25).

Победившим считался кандидат, набравший больше половины голосов избирателей (ст.56). В том случае, если ни один из кандидатов в судьи по избирательному округу не набрал необходимого числа голосов, исполком районного или городского Совета депутатов трудящихся был обязан немедленно сообщить об этом Президиуму Верховного Совета АССР или исполкому краевого, областного Совета депутатов трудящихся. Затем следовало объявить перебаллотировку кандидатов, получивших наибольшее число голосов. Второй тур выборов следовало провести не позднее, чем в двухнедельный срок после первого тура (ст.60).
В случае выбытия народного судьи до истечения срока его полномочий, новые выборы следовало организовать не позднее двухмесячного срока со дня досрочного прекращения полномочий народного судьи (ст. 65).

Правительство уделило большое внимание подготовке выборов по новому закону. Еще 13 сентября 1948 г., то есть почти за две недели до окончательного принятия Положения «О выборах народных судов РСФСР» состоялось заседание Политбюро, на котором было принято следующее постановление:

1. Провести выборы народных судов (народных судей и народных заседателей) в период декабрь 1948-февраль 1949 г.

2. Обязать ЦК компартий союзных республик, крайкомы и обкомы ВКП (б) установить день выборов народных судов в пределах срока, указанного в п.1 настоящего постановления, а также организовать подбор кандидатов в народные судьи и народные заседатели и приступить к разработке организационнотехнических мероприятий, связанных с проведением выборов народных судов

3. Обязать ЦК компартий союзных республик рассмотреть и утвердить Положение о выборах народных судов применительно к каждой Союзной республике.

Положение о выборах народных судов РСФСР поручить рассмотреть и утвердить Секретариату ЦК ВКП(б) $)^{12}$.

25 сентября 1948 г. министр юстиции СССР издал приказ:

«...2) Считать подбор кандидатов в народные судьи одной и важнейших задач МЮ (Министерства юстиции - Д. С.) ... В связи с этим проверить, опираясь на помощь партийных организаций, каждого ныне работающего народного судью, тщательно разобраться в том, он проводит политическую линию партии в своей работе и определить, возможно ли по политическим и деловым качествам судьи рекомендовать его кандидатом при выборах народных судов. В этих же целях немедленно тщательно проверить все имеющиеся сигналы о недостатках, неправильных действиях и злоупотреблениях отдельных народных судей и принять по ним окончательные меры.

3) Подобрать и представить в партийные органы кандидатов в народные судьи, отвечающих высокому званию судей как в политическом, так и деловом отношении, достойных доверия народа, способных по-большевистки выполнять ответственные задачи по осуществлению правосудия, являть образец честного

\footnotetext{
${ }^{12}$ РГАСПИ. Ф. 17. Оп. 3. Д. 1072. Л. 41.
} 
DOI: $10.7256 / 1811-9018.2014 .1 .10264$

При цитировании этой статьи сноска на ооі обязательна

\section{Право и политика 1 (169) 2014}

служения Родине, точного и неуклонного исполнения советских законов, моральной чистоты и безукоризненного поведения...

4) В тех случаях, когда ныне работающие народные судьи не будут выставлены кандидатами при выборах народных судов, вместо них подобрать и представить в партийные органы кандидатов, отвечающих всем требованиям, из числа членов и кандидатов партии, имеющих юридическое образование или опыт юридической работы и работающих в других ведомствах, а также из числа лиц, окончивших в 1948 г. юридические институты и юридические школы. Рекомендуется также выдвинуть кандидатами в народные судьи лучших ревизоров и консультантов Министерства Юстиции и их управлений в краях и областях, отвечающих установленным требованиям» ${ }^{13}$.

На основе анализа значительного массива архивных данных, А.Я. Кодинцев выделяет следующую последовательность при подготовке к выборам народных судей. Сначала поступала директива ЦК. Затем принималась директива обкома. В октябре 1948 г. райисполкомы образовывали избирательные пункты, утверждали состав уполномоченных при избирательных пунктах, утверждали членов счетных комиссий. Райкомы персонально проводили беседы с народными заседателями. Составлялся план о порядке проведения собраний по выдвижению кандидатов в народные судьи и народные заседатели.

Затем проводились инструктивные совещания с участием председателей сельсоветов, уполномоченных райисполкомов при избирательных пунктах, секретарей партийных комитетов, руководителей агитгрупп, райкомов; проводились собрания по «выдвижению» кандидатов. На них выдвигали по 1 кандидату в народные судьи и по 60 в народные заседатели, а также выдвигались делегаты на окружные предвыборные совещания. Кандидатов направляло управление министерства юстиции. Затем кандидаты регистрировались в райисполком. Следующим этапом являлось окружное избирательное собрание. За это время уточнялся состав избирателей. Работники органов юстиции читали лекции и доклады. Агитгруппы проводили беседы. Обком регулярно заслушивал доклады о подготовке к выборам. Общий срок подготовки к выборам составлял 3 месяца ${ }^{14}$.

Выборы по всей стране были проведены с 19 декабря 1948 г. по 20 февраля 1949 г. ${ }^{15}$ Явка на них оказалось

\footnotetext{
${ }^{13}$ ГА РФ. Ф. Р-9492. Оп. 4. Д. 401. Л. 67-68.

${ }^{14}$ Кодинцев А. Я. Выборы народных судей...

${ }^{15}$ РГАСПИ. Ф 17. Оп. 3. Д. 1074. Л. 117.
}

чрезвычайно высокой, что свидетельствует о задействовании административного ресурса.

Так, 20 февраля 1949 г. секретарь МК и МГК ВКП (б) докладывал В.М. Молотову: «Выборы народных судов в г. Москве и Московской области шли с большим политическим подъемом». Явка на избирательные участки составила 99,9 процентов в самой Москве, и столько же - в Московской области. Всего по Москве и Московской области приняло участие в голосовании 5826983 избирателей, или 99,9\% ${ }^{16}$.

Аналогичные цифры были характерны как для РСФСР, так и для всего Союза в целом; в РСФСР приняло участие в голосовании 99,87\% населения. Самые «низкие» показатели по явке избирателей показали жители Эстонской ССР - 99,38\%, самые высокие - Азербайджанской ССР - 99,9\% ${ }^{17}$. Результаты голосования оказались положительными: всего по союзным республикам было подано голосов против кандидатов в судьи $0,7 \%{ }^{18}$.

12 марта 1949 г. принято решение утвердить текст сообщения о результатах выборов народных судей и народных заседателей ${ }^{19}$.

Три года спустя было разработано новое положение о выборах народных судов. 27 июля 1951 г. состоялось заседание Политбюро, на котором собравшиеся приняли решение: 1) о проведении выборов народных судов РСФСР в воскресенье 16 декабря 1951 г.; 2) об утверждении: а) проекта указа Президиума Верховного Совета РСФСР «О проведении выборов народных судов РСФСР»; б) проекта «Положения о выборах народных судей РСФСР и рекомендации его в качестве типового положения для других союзных республик ${ }^{20}$.

Новое положение о выборах народных судей было принято 29 октября 1951 г. $^{21}$ По сути, оно представляло собой Положение «О выборах народных судов РСФСР» 1948 г. с незначительными поправками. К числу относительно значимых изменений можно отнести введение единого дня выборов для РСФСР; право его установления передавалось Президиуму Верховного Совета РСФСР (ст.37) и т.д.

\footnotetext{
${ }^{16}$ РГАСПИ. Ф. 82. ОП. 2. Д. 891. Л.125.

${ }^{17}$ РГАСПИ. Ф. 17. Оп. 3. Д. 1074. Л. 117.

${ }^{18}$ Там же. Л. 119.

${ }^{19}$ Там же. Л. 66.

${ }^{20}$ РГАСПИ. Ф. 17. ОП. 3. Д. 1089. Л.114.

${ }^{21}$ Положение о выборах народных судов РСФСР (утв. Указом Президиума Верховного Совета РСФСР от 29.10.1951). М.:Госюриздат,1954.
} 
При организации новых выборов на министерствах юстиции союзных и автономных республик, на краевых и областных управлениях юстиции лежала большая работа по подведению итогов деятельности каждого народного судьи, оценке его деловых и политических качеств, поскольку именно на министерства и их областные управления была возложена обязанность первыми высказывать свое мнение в партийных органах о возможности или невозможности повторного выдвижения кандидата.

Принимало участие в подготовке и проведении выборов и союзное министерство. Так, за время подготовки к выборам народных судей в 1954 г., 63 оперативных и руководящих работника министерства юстиции $\mathrm{CCCP}$, в т.ч. члены коллегии и 4 из 5 заместителей министра побывали в 67 областях, краях и республиках с целью оказания помощи министрам и начальникам Управлений Министерств юстиции ${ }^{22}$.

Подводя итог избирательной кампании 1954 г., министерство юстиции отметило и те отрицательные явления, которые проявились в процессе подготовки и проведения выборов, работы с кадрами. Во-первых, отмечались многочисленные серьезные ошибки, допущенные министерствами юстиции и управлениями юстиции в краях и областях при подборе кандидатов в народные судьи, как во время предыдущей избирательной кампании, так и во время подбора кандидатов в связи с досрочным освобождением судей. Во-вторых, шла жесткая критика повседневного контроля за деятельностью народных судей, плохой воспитательной работы. Многочисленные требования со стороны министерства юстиции о ежегодном проведении ревизии каждого народного суда не способствовали усилению контроля за деятельностью народных судов, а, наоборот, ослабляли его. Не везде имелась возможность обревизовать каждый народный суд в связи с незначительностью персонала; там же, где такая возможность имелась, ревизию проводили вне зависимости от того, нуждается в ней суд или нет, оставляя без внимания тех народных судей, которые действительно нуждались в проверке. В связи с этим было выдвинуто предложение впредь оценивать работу министерств юстиции союзных республик, областных и краевых управлений не по числу проведенных ревизий народных судов, а по состоянию судебной работы в республике или области по состоянию идейно-политического воспитания кадров и повышения их квалификации ${ }^{23}$.
Обобщая вышеизложенное, отметим. После окончания Великой Отечественной войны и возобновления работы судов общей юрисдикции в прежнем режиме был продолжен процесс законотворчества в судебной сфере. Принятие закона о выборах народных судей сыграло значительную роль в формировании статуса судей, означало важный шаг по пути к становлению действенной судейской независимости от органов исполнительной власти. Низкоквалифицированный состав судейского корпуса стал причиной повышения требований к кандидатам, что повлекло за собой внесение изменений не только в республиканское, но и в союзное законодательство.

\section{Библиография:}

1. Г. Кодинцев А.Я. Выборы народных судей СССР в 1948-1954 гг.: [Электронный ресурс]. Доступ из справочно-правовой системы «КонсультантПлюс»

2. Кодан С.В. Система законодательства в России: формирование, развитие, становление (IX - начало $\mathrm{XX}$ вв.) // NB: Проблемы общества и политики. 2013. - 4. - C. 239-293. URL: http://www.e-notabene. $\mathrm{ru} / \mathrm{pr} /$ article_436.html

3. Никулин В.В. Партийно-государственная номенклатура и закон в советской России: двойная ответственность или особые правовые условия (1920-е годы) // NB: Исторические исследования. - 2013. - 3. - C. 1 - 43. URL: http://www.e-notabene. $\mathrm{ru} / \mathrm{hr} /$ article_750.html

\section{References (transliteration):}

1. G. Kodintsev A.Ya. Vybory narodnykh sudei SSSR v 1948-1954 gg.: [Elektronnyi resurs]. Dostup iz spravochno-pravovoi sistemy «Konsul'tantPlyus»

2. Kodan S.V. Sistema zakonodatel'stva v Rossii: formirovanie, razvitie, stanovlenie (IX - nachalo XX vv.)//NB: Problemy obshchestva i politiki. - 2013. - 4. - C. 239 - 293. URL: http://www.e-notabene.ru/pr/article_436.html

3. Nikulin V.V. Partiino-gosudarstvennaya nomenklatura i zakon v sovetskoi Rossii: dvoinaya otvetstvennost' ili osobye pravovye usloviya(1920-e gody) // NB: Istoricheskie issledovaniya. - 2013. - 3. - C. $1-43$. URL: http://www.e-notabene.ru/hr/article_750.html

\footnotetext{
${ }^{22}$ ГА РФ. Ф. Р-9492. Оп. 1. Д. 786. Л. 3.

${ }^{23}$ Там же. Лл. 8-10.
} 